\title{
THE EFFECT OF DROTAVERINE ON CERVICAL DILATATION- A COMPARATIVE STUDY WITH HYOSCINE IN FIRST STAGE OF LABOUR
}

\author{
Gautam Mukhopadhyay', Arijit Das ${ }^{2}$
}

${ }_{1}^{1}$ Associate Professor, Department of Obstetrics and Gynaecology, North Bengal Medical College, West Bengal, India.

${ }_{2}^{2}$ Medical Officer, Department of Obstetrics and Gynaecology, North Bengal Medical College, West Bengal, India.

ABSTRACT
BACKGROUND
Prolonged labour caused by cervical spasm is associated with many maternal and perinatal complications including infection.
Various antispasmodic drugs relieve cervical spasm and facilitate cervical dilatation during the first stage of labour and thereby
reduce the duration of labour.

\section{MATERIALS AND METHODS}

This is a prospective randomised study carried out over one year in a tertiary hospital. Two hundred patients in labour were randomly allocated into two groups as follows:

Gr A- 100 patients in labour ( $>4 \mathrm{~cm}$ cervical dilatation) were given IV injection of drotaverine hydrochloride.

Gr B- 100 patients in labour were given Inj. Hyoscine Butylbromide.

The efficacy of drotaverine with hyoscine for increasing the rate of cervical dilatation in first stage of labour were compared. The main outcome measures were the rate of cervical dilatation, time taken for full cervical dilatation, duration of first and second stage of labour and all calculated separately for nulliparas and multiparas in two groups. Statistical analysis was done by student's 't' test.

\section{RESULTS}

There was no statistically significant difference in two groups in regard to gestational age, parity, average dilatation of cervix at injection of antispasmodic agents. Average time for full cervical dilatation was significantly less in Gr. B in both multipara (p < 0.05$)$ and nullipara $(p<0.01)$. Similarly, the average rate of cervical dilatation was significantly more in Group B, both in nulliparas ( $<<$ 0.007 ) and multiparas ( $p<0.02$ ). When Bishop's score was taken as baseline, the same finding was obtained. Regarding side effects, there was no significant difference between the two drugs. The difference in the duration of second and third stage of labour were statistically insignificant.

\section{CONCLUSION}

The rate of cervical dilatation under the influence of hyoscine butylbromide is significantly higher as compared to that with drotaverine hydrochloride. Both the drugs were found to be safe without any adverse maternal or foetal side effects.

\section{KEY WORDS}

Hyoscine Butylbromide, Drotaverine, Labour, Cervical Dilatation.

HOW TO CITE THIS ARTICLE: Mukhopadhyay G, Das A. The effect of drotaverine on cervical dilatation- a comparative study with hyoscine in first stage of labour. J. Evolution Med. Dent. Sci. 2018;7(30):3369-3372, DOI: 10.14260/jemds/2018/760

\section{BACKGROUND}

To reduce the total duration of labour without affecting the maternal and foetal outcome remains the primary goal of every obstetrician. To accomplish this, many methods have been adopted including augmentation of labour by intravenous oxytocin and/ or by early amniotomy. Many people use various antispasmodic agents like drotaverine, hyoscine, dicyclomine and valethamate bromide to accelerate the first stage of labour, thereby reducing the sufferings of labouring mother. The present study compares the relative efficacy of hyoscine versus drotaverine in reducing the duration of first stage of labour.

'Financial or Other Competing Interest': None.

Submission 28-10-2017, Peer Review 09-07-2018,

Acceptance 17-07-2018, Published 23-07-2018.

Corresponding Author:

Gautam Mukhopadhyay,

4A, Triveni Apartment,

Meghnad Saha Sarani,

Pradhan Nagar, Siliguri-District,

Darjeeling-734003, West Bengal, India.

E-mail: gautam_in_66@yahoo.co.uk

DOI: $10.14260 /$ jemds $/ 2018 / 760$

\section{MATERIALS AND METHODS}

This is a non-randomised controlled trial, which was undertaken in the Department of Obstetrics and Gynaecology, North Bengal Medical College, a tertiary hospital from March 2013 to February 2014. The trial was conducted on 200 women in labour who were non-randomly allocated to Group A or Group B.

The following are exclusion criteria namely preterm labour, absent membrane, APH, history of cervical encirclage, malpresentation and IUFD. Active management of first stage of labour was followed using partogram. No intervention was done till $4 \mathrm{~cm}$ of cervical dilation, following which oxytocin infusion was started at the rate of $6 \mathrm{mIU} / \mathrm{mL}$ and titrated according to the uterine contractions. Artificial rupture of membrane was done at $4-5 \mathrm{~cm}$ dilatation along with IV injection of either of the two drugs in study. Cervical assessment was done every 4 hours or earlier if otherwise indicated. The time interval between admission and $4 \mathrm{~cm}$ cervical dilatation and injection of antispasmodic to full cervical dilatation were noted. The duration of second and third stage of labour were noted. The pulse rate of mother was monitored every 15 mins for one hour after injection of 
drugs under study. Foetal heart rate was also monitored every 15 mins using Doppler.

Each group was further divided into one of multiparas and one of nulliparas. Within these two subgroups, further division was done depending upon whether the antispasmodic was given at less than $5 \mathrm{~cm}$ cervical dilatation or more than $5 \mathrm{~cm}$ cervical dilatation. The women are further divided into two groups depending on initial Bishop's score $<10$ or $>10$. The time taken for full cervical dilatation and the rate of cervical dilatation for each of eight subgroups were calculated. Note was also made on the side effects of each drug. Statistical analysis was done by the student's ' $t$ ' test.

\section{Calculation of Sample Size}

The primary outcome of interest is the mean difference in an outcome variable between two treatment groups. For example, it is postulated that a good clinical response to difference between the active and placebo group is 0.2 units with an SD of 0.5 units and how many subjects will be required to obtain a statistical significance for this clinical difference?

A simple formula for a two-sided test of $5 \%$ is $m$ (Size per group) $=\left[2 \mathrm{c} / \delta^{2}+1\right]$ where $\delta=I \mu 1-\mu 2 \mathrm{I} / \sigma$ is the standardised effect size and $\mu 1$ and $\mu 2$ are the means of the two treatment groups. $\sigma$ is the common standard deviation. $\mathrm{C}=7.9$ for $80 \%$ power and 10.5 for $90 \%$ power.

From the above example, $\delta=0.2 / 0.5=0.4$ and for $80 \%$ power, we have $\mathrm{m}$ (size per group) $=(2 \times 7.9) /(0.4 \times 0.4)$ $+1=99.75>>100$. Hence, $100 \times 2=200$ subjects will be needed, 100 in each group.

\section{Software used for Statistical Analysis}

IBM Corp. Released 2013. IBM SPSS Statistics for Windows, Version 22.0. Armonk, NY; IBM Corp.

Delta, alpha, beta value. All have been assumed to a particular study for calculating the sample size.

\section{RESULTS}

The maternal characteristics were comparable in the two groups without having any significant difference in the parameters (Table I). The average time taken from the time of injection of antispasmodic to the full cervical dilatation of cervix in nulliparas with baseline dilatation $<5 \mathrm{~cm}$ in Group A was 105.57 mins and in Group B it was 57.66 mins ( $p<0.01)$. While with baseline dilatation $>5 \mathrm{~cm}$, it was 116 mins in Group A and 68.48 mins in Group B ( $p<0.01)$.

In multiparas with baseline dilatation $<5 \mathrm{~cm}$, the time taken for full cervical dilatation in Group A was 119 mins and in Group B it was 62.38 mins $(p<0.05)$. While with baseline dilatation $>5 \mathrm{~cm}$, the average time to full dilatation was 106.48 mins in Group A and 63.20 mins in Group B respectively $(p<0.05)$ (Table 2$)$.

The rate of cervical dilatation in the nulliparas with baseline cervical dilatation $<5 \mathrm{~cm}$ in group was $2.82 \mathrm{~cm} /$ hour and in Group B it was $5.12 \mathrm{~cm} / \mathrm{hr}(\mathrm{p}<0.001)$. With the cervical dilation $>5 \mathrm{~cm}$, the average rate of cervical dilatation was $2.5 \mathrm{~cm}$ in Group A and in Group b it was $4.5 \mathrm{~cm} /$ hour $(\mathrm{p}<0.001)$.

In multiparas the rate with cervix $<5 \mathrm{~cm}$ dilated in Group A was $2.58 \mathrm{~cm} / \mathrm{hr}$ and in Group B it was $4.89 \mathrm{~cm} / \mathrm{hr}(\mathrm{p}<$
0.02), while with baseline cervical dilatation $>5 \mathrm{~cm}$ in Group A it was $2.86 \mathrm{~cm} / \mathrm{hr}$ and in Group B it was $4.89 \mathrm{~cm} /$ hour $(\mathrm{p}<0.03)$ (Table 3).

Taking the Bishop's score as baseline in nulliparas with Bishop's score $<10$, the rate of cervical dilatation in Group A was $2.2 \mathrm{~cm} /$ hour and in Group B it was $3.78 \mathrm{~cm} /$ hour $(p<0.03)$, while with Bishop's score $>10$ the rate was 2.63 $\mathrm{cm} /$ hour and $4.68 \mathrm{~cm} /$ hour in Group A and Group B respectively ( $\mathrm{p}<0.05)$.

In multiparas in subgroup with Bishop's score $<10$ in Group A it was $2.36 \mathrm{~cm} /$ hour and in Group B it was 4.73 $\mathrm{cm} /$ hour $(\mathrm{p}<0.01)$, while in subgroup with Bishop's score $>10$ the rate in Group A was $2.79 \mathrm{~cm} / \mathrm{hr}$ and in Group B it was $4.39 \mathrm{~cm} / \mathrm{hr}(\mathrm{p}<0.02)$ (Table 4).

The differences in the duration of second and third stage of labour in both the groups were not statistically significant as evidenced in Table 5 .

A rise in maternal pulse rate upto 8 - 10 beats per minute was detected within 10 minutes of injection of hyoscine. However, the pulse rate was normalised within the next 15 minutes. No complaints were there from the patients during this time. An inconsistent rise of pulse rate of upto 5 - 6 beats per minute was observed with drotaverine hydrochloride injection, which was settled over next 10 - 15 minutes time without any complaint from the patient.

\begin{tabular}{|c|c|c|c|c|c|}
\hline $\begin{array}{c}\text { Sl. } \\
\text { No. }\end{array}$ & Variable & $\begin{array}{c}\text { Group A } \\
\text { (Drotaverine) } \\
\mathbf{N}=\mathbf{1 0 0}\end{array}$ & $\begin{array}{c}\text { Group B } \\
\text { (Hyoscine) } \\
\mathrm{N}=100\end{array}$ & $\begin{array}{c}\text { ' } T \text { ' } \\
\text { Value }\end{array}$ & $\begin{array}{c}\text { 'P' } \\
\text { Value }\end{array}$ \\
\hline 1. & $\begin{array}{c}\text { Average } \\
\text { Gestational } \\
\text { Age (Days) }\end{array}$ & $\begin{array}{c}276.47 \pm \\
6.01\end{array}$ & $\begin{array}{c}275.29 \pm \\
6.48\end{array}$ & 0.26 & $p>0.05$ \\
\hline 2. & $\begin{array}{c}\text { Average } \\
\text { Dilatation } \\
<5 \mathrm{~cm}\end{array}$ & $\begin{array}{l}3.56 \pm \\
0.615\end{array}$ & $\begin{array}{l}3.58 \pm \\
0.620\end{array}$ & 0.39 & $p>0.05$ \\
\hline 3. & $\begin{array}{l}\text { Average } \\
\text { Dilatation } \\
>5 \mathrm{~cm}\end{array}$ & $\begin{array}{c}5.876 \pm \\
0.480\end{array}$ & $\begin{array}{c}6.71 \pm \\
1.42\end{array}$ & 0.56 & $p>0.05$ \\
\hline 4. & $\begin{array}{c}\text { Average } \\
\text { Dilatation at } \\
\text { Injection } \\
(\mathrm{cm})\end{array}$ & $\begin{array}{c}4.18 \pm \\
1.18\end{array}$ & $\begin{array}{c}4.20 \pm \\
1.35\end{array}$ & 0.57 & $p>0.05$ \\
\hline 5. & $\begin{array}{c}\text { Average } \\
\text { Bishop's } \\
\text { Score } \leq 10\end{array}$ & $\begin{array}{c}8.30 \pm \\
1.07\end{array}$ & $\begin{array}{l}8.19 \pm \\
0.732\end{array}$ & 0.75 & $p>0.05$ \\
\hline 6. & $\begin{array}{c}\text { Average } \\
\text { Bishop's } \\
\text { Score > } 10\end{array}$ & $\begin{array}{c}10.725 \pm \\
0.708\end{array}$ & $\begin{array}{c}10.324 \pm \\
0.643\end{array}$ & 1.49 & $p>0.05$ \\
\hline
\end{tabular}

Table 1. Comparison of the Two Groups

\begin{tabular}{|c|c|c|c|c|}
\hline $\begin{array}{c}\text { Baseline } \\
\text { Dilatation }\end{array}$ & $\begin{array}{c}\text { Group A } \\
\text { Drotaverine }\end{array}$ & $\begin{array}{c}\text { Group B } \\
\text { Hyoscine }\end{array}$ & $\begin{array}{c}\text { 'T' } \\
\text { Value }\end{array}$ & $\begin{array}{c}\text { 'P' } \\
\text { Value }\end{array}$ \\
\hline \multicolumn{5}{|c|}{ Nulliparas } \\
\hline$<5 \mathrm{~cm}$ & $105.568 \pm 14.4$ & $57.66 \pm 66.2$ & 3.24 & $<0.01$ \\
\hline$>5 \mathrm{~cm}$ & $116 \pm 22.5$ & $68.48 \pm 15.3$ & 2.18 & $<0.05$ \\
\hline \multicolumn{5}{|c|}{ Multiparas } \\
\hline$<5 \mathrm{~cm}$ & $119 \pm 92.6$ & $62.380 \pm 56.9$ & 2.02 & $<0.05$ \\
\hline$>5 \mathrm{~cm}$ & $106.48 \pm 66.6$ & $63.20 \pm 18.0$ & 2.06 & $<0.05$ \\
\hline
\end{tabular}

Table 2. Average Time from Injection of Antispasmodic to Full Cervical Dilatation (in Minutes) 


\begin{tabular}{|c|c|c|c|c|}
\hline $\begin{array}{c}\text { Baseline } \\
\text { Dilatation }\end{array}$ & $\begin{array}{c}\text { Group A } \\
\text { Drotaverine }\end{array}$ & $\begin{array}{c}\text { Group B } \\
\text { Hyoscine }\end{array}$ & \begin{tabular}{|c|} 
'T' \\
Value \\
\end{tabular} & $\begin{array}{c}P^{\prime} \\
\text { Value }\end{array}$ \\
\hline \multicolumn{5}{|l|}{ Nulliparas } \\
\hline$<5 \mathrm{~cm}$ & $\begin{array}{c}0.048 \pm 0.0312 \\
=2.82 \mathrm{~cm} / \mathrm{hr}\end{array}$ & $\begin{array}{c}0.840 \pm 0.04 \\
=5.12 \mathrm{~cm} / \mathrm{hr}\end{array}$ & 2.89 & $<0.001$ \\
\hline$>5 \mathrm{~cm}$ & $\begin{array}{c}0.0442 \pm \\
0.0489 \\
=2.5 \mathrm{~cm} / \mathrm{hr} \\
\end{array}$ & $\begin{array}{c}0.0752 \pm \\
0.0627 \\
4.5 \mathrm{~cm} / \mathrm{hr}\end{array}$ & 5.3 & $<0.001$ \\
\hline \multicolumn{5}{|l|}{ Multiparas } \\
\hline$<5 \mathrm{~cm}$ & $\begin{array}{c}0.0425 \pm \\
0.0202 \\
=2.58 \mathrm{~cm} / \mathrm{hr}\end{array}$ & $\begin{array}{c}0.0817 \pm \\
0.0490 \\
4.89 \mathrm{~cm} / \mathrm{hr}\end{array}$ & 2.55 & $<0.02$ \\
\hline$>5 \mathrm{~cm}$ & $\begin{array}{c}0.0470 \pm 0.036 \\
=2.86 \mathrm{~cm} / \mathrm{hr}\end{array}$ & $\begin{array}{c}0.0824 \pm 0.046 \\
=4.88 \mathrm{~cm} / \mathrm{hr}\end{array}$ & 2.26 & $<0.03$ \\
\hline
\end{tabular}

\begin{tabular}{|c|c|c|c|c|}
\hline $\begin{array}{c}\text { Baseline } \\
\text { Bishop's } \\
\text { Score } \\
\end{array}$ & $\begin{array}{c}\text { Group A } \\
\text { Drotaverine }\end{array}$ & $\begin{array}{l}\text { Group b } \\
\text { Hyoscine }\end{array}$ & $\begin{array}{c}\text { 'T' } \\
\text { Value }\end{array}$ & $\begin{array}{c}\text { 'P' } \\
\text { Value }\end{array}$ \\
\hline \multicolumn{5}{|l|}{ Nulliparas } \\
\hline$<10$ & $\begin{array}{c}0.0369 \pm \\
0.021 \\
=2.20 \mathrm{~cm} / \mathrm{hr} \\
\end{array}$ & $\begin{array}{c}0.0640 \pm \\
0.0379 \\
=3.78 \mathrm{~cm} / \mathrm{hr} \\
\end{array}$ & 2.28 & $\begin{array}{l}<0.03 \\
\text { Significant }\end{array}$ \\
\hline$\geq 10$ & $\begin{array}{c}0.0457 \pm \\
0.172 \\
=2.63 \mathrm{~cm} / \mathrm{hr} \\
\end{array}$ & $\begin{array}{c}0.078 \pm \\
0.0130 \\
=4.68 \mathrm{~cm} / \mathrm{hr}\end{array}$ & 0.32 & $\begin{array}{l}>0.05 \\
\text { N.S. }\end{array}$ \\
\hline \multicolumn{5}{|c|}{\begin{tabular}{|l|l|l} 
Multiparas & & \\
\end{tabular}} \\
\hline$<10$ & $\begin{array}{c}0.0398 \pm \\
0.0168 \\
=2.36 \mathrm{~cm} / \mathrm{hr}\end{array}$ & $\begin{array}{c}0.0799 \pm \\
0.0429 \\
=4.73 \mathrm{~cm} / \mathrm{hr} \\
\end{array}$ & 3.15 & $\begin{array}{l}<0.01 \\
\text { H.S. }\end{array}$ \\
\hline$\geq 10$ & $\begin{array}{c}0.0466 \pm \\
0.0273 \\
=2.79 \mathrm{~cm} / \mathrm{hr} \\
\end{array}$ & $\begin{array}{c}0.0806 \pm \\
0.0421 \\
=4.39 \mathrm{~cm} / \mathrm{hr} \\
\end{array}$ & 2.44 & $\begin{array}{l}<0.02 \\
\text { S.D. }\end{array}$ \\
\hline \multicolumn{5}{|c|}{$\begin{array}{l}\text { Table 4. Average Rate of Cervical Dilatation with Bishop's } \\
\text { Score (cm/hr) }\end{array}$} \\
\hline
\end{tabular}

\begin{tabular}{|c|c|c|c|c|}
\hline $\begin{array}{c}\text { Average } \\
\text { Duration } \\
\text { (Minutes) }\end{array}$ & $\begin{array}{c}\text { Group A } \\
\text { Drotaverine }\end{array}$ & $\begin{array}{c}\text { Group B } \\
\text { Hyoscine }\end{array}$ & $\begin{array}{c}\text { 'T' } \\
\text { Value }\end{array}$ & $\begin{array}{c}\text { 'P' } \\
\text { Value }\end{array}$ \\
\hline $2^{\text {nd }}$ stage & & & & \\
\hline Nulliparas & $34.43 \pm 6.58$ & $34.58 \pm 5.58$ & 0.54 & $>0.05$ \\
\hline Multiparas & $22.56 \pm 5.1$ & $22.46 \pm 1.84$ & 0.42 & $>0.05$ \\
\hline $3^{\text {rd }}$ Stage & & & & \\
\hline Nulliparas & $5.8 \pm 1.84$ & $5.6 \pm 1.86$ & 0.51 & $>0.05$ \\
\hline Multiparas & $4.6 \pm 2.0$ & $4.7 \pm 1.58$ & 0.44 & $>0.05$ \\
\hline \multicolumn{6}{|c|}{ Table 5. Duration of Second and Third Stages of Labour } \\
\hline
\end{tabular}

\section{DISCUSSION}

The hazards of prolonged labour for the mother such as infection, ketosis and obstructed labour have been recognised for many years. The foetus faces the dangers of infection, asphyxia and excessive cranial moulding due to prolonged labour. The concept of active management of labour was introduced by O'Driscoll (1973). ${ }^{1}$ Attempts to accelerate labour and thereby shorten its duration without jeopardising maternal and foetal outcome are welcome to both the patient and the obstetrician. The two basic factors that determine the duration of labour are uterine activity and the rate of cervical dilatation.

Cervical ripening, expressed as a remodelling of the cervical connective tissue, has been proven to be necessary for an uncomplicated vaginal delivery. ${ }^{2}$ Inability of the cervix to ripen and dilate is still acknowledged as a cause of nonprogress of labour. Recent biochemical evidence also

suggests that the cervix could obstruct labour by sustained spasm due to insufficient connective tissue remodelling.

It is a known fact that $10 \%-15 \%$ of the non-pregnant cervix is constituted by smooth muscle fibres. ${ }^{3}$

Besides a decrease in fibrous connective tissue in the cervix at term, there is an increase in the proportion of smooth muscle fibres, which also become dissociated and hypertrophic and aligned in a particular direction. ${ }^{3}$

These studies relating to the presence of smooth muscle fibres in the cervix logically support the role of antispasmodics and smooth muscle relaxants in helping the cervix to dilate. Drotaverine hydrochloride and hyoscine butylbromide are two such smooth muscle relaxants with different mechanism of action.

Hyoscine, a quaternary derivative of atropine, is an antimuscarinic agent which acts by inhibiting cholinergic transmission in the parasympathetic ganglia, thus relieving spasm in the smooth muscle of female genital organs, especially the cervicouterine plexus, thus aiding cervical dilatation. Uterine contractions are not affected. Due to better coordination between uterine contractions and cervical dilatation, labour is accelerated. Being a quaternary ammonium derivative, it does not cross the blood brain barrier, so central effects if any are rare. Also, there are no known foetal effects of this compound. 4

Drotaverine hydrochloride or isoquinoline 1,2,3,4tetrahydro 6,7 diethoxy-1-(c-3,4- diethoxy phenyl methylene) hydrochloride is a highly potent spasmolytic agent, acting on the smooth muscle but is devoid of anticholinergic effects as it acts through inhibitory effect on phosphodiesterase enzyme, mainly PDEIV. Near term, human myometrium contains a higher proportion of rolipram sensitive type IVPDE isoforms. Drotaverine inhibits them and in turn increase the intracellular concentration of cAMP and cGMP and causes smooth muscle relaxation. It does not cross the placenta, hence no side effects on the foetus. ${ }^{5}$

In our series, it was found that injection of hyoscine caused faster progress of labour compared to drotaverine group and it was statistically significant, and it was seen in both nulliparas and multiparas including whether the injection was given either $<5 \mathrm{~cm}$ or $>5 \mathrm{~cm}$ cervical dilatation.

Similar results were also shown by other workers (Tehlia Manpreet et al). 6

However, Gupta $\mathrm{B}^{7}$ in a randomised control trial in women in labour failed to demonstrate any statistically significant role of drotaverine and hyoscine injection in augmentation of labour when it was compared with control with no drugs.

\section{CONCLUSION}

Hyoscine butylbromide has a definite advantage over drotaverine hydrochloride injection and remains the drug of choice to hasten the progress of first stage of labour.

\section{REFERENCES}

[1] O'Driscoll K, Stronge JM, Minogue M. Active management of labour. British Medical Journal 1973;3(5872):135-7.

[2] Granstrom L, Ekman G, Malmstrom A. Insufficient remodelling of the uterine connective tissue in women with protracted labour. $\mathrm{Br} \mathrm{J}$ Obstet Gynaecol 1991;98(12):1212-6. 
[3] Minamoto $\mathrm{T}$, Arai $\mathrm{K}$, Hirakawa $\mathrm{S}$, et al. Immunohistochemical studies on collagen types in uterine cervix In pregnant and non-pregnant states. Am J Obstet Gynaecol 1987;156(1):138-44.

[4] Samuels LA, Christie L, Roberts-Gittens B, et a. The effect of Hyoscine butylbromide on the first stage of labor in term pregnancies. BJOG 2007;114(12):15426.

[5] Mishra SL, Toshniwal A, Banerjee R. Effect of Drotaverine on cervical dilatation: a comparative study with epidosin (valethamate bromide). The J Obstet Gynaecol of India 2002;52(3):76-9.
[6] Manpreet TK, Gouramba SR, Jyothi $\mathrm{K}$, et al. A comparative study of Hyoscine butylbromide versus Drotaverine hydrochloride in first stage of labor. J Obstet Gynecol India 2008;58(3):230-4.

[7] Gupta B, Nellore V, Mittal S. Drotaverine hydrochloride versus hyoscine-N-butylbromide in augmentation of labor. International Journal of Gynaecology and Obstetrics 2008;100(3):244-7. 